Bond University

Research Repository

\title{
Competencies for managing change
}

\section{Crawford, Lynn; Nahmias, Anat Hassner}

Published in:

International Journal of Project Management

DOI:

10.1016/j.ijproman.2010.01.015

\section{Licence:}

CC BY-NC-ND

Link to output in Bond University research repository.

Recommended citation(APA):

Crawford, L., \& Nahmias, A. H. (2010). Competencies for managing change. International Journal of Project Management, 28(4), 405-412. https://doi.org/10.1016/j.ijproman.2010.01.015

\footnotetext{
General rights

Copyright and moral rights for the publications made accessible in the public portal are retained by the authors and/or other copyright owners and it is a condition of accessing publications that users recognise and abide by the legal requirements associated with these rights.
}

For more information, or if you believe that this document breaches copyright, please contact the Bond University research repository coordinator. 


\section{Bond University}

\section{ePublications@bond}

Mirvac School of Sustainable Development

Institute of Sustainable Development and

Architecture

$1-1-2010$

\section{Competencies for managing change}

Lynn Crawford

Bond University, Lynn_Crawford@bond.edu.au

Anat Hassner Nahmias

Human Capital Practice, Presence of IT, Sydney

Follow this and additional works at: http://epublications.bond.edu.au/sustainable_development

Part of the Business Administration, Management, and Operations Commons

\section{Recommended Citation}

Lynn Crawford and Anat Hassner Nahmias. (2010) "Competencies for managing change"

International journal of project management, 28 (4), 405-412.

http://epublications.bond.edu.au/sustainable_development/57 


\title{
Competencies for Managing Change
}

\author{
Professor Lynn Crawford \\ Univ Lille Nord de France, F-59000 Lille, France; LSMRC \\ Mirvac School of Sustainable Development, Bond University, Australia \\ Visiting Professor, Cranfield University, UK \\ Director, Human Systems International Limited \\ and \\ Dr Anat Hassner Nahmias \\ Change Management Leader, Human Capital Practice, Presence of IT
}

\begin{abstract}
Organisational changes are now recognised as a specific project type that can benefit from the application of project management skills, tools and techniques. Associated with this trend is evidence of a degree of rivalry in the marketplace between Project Managers and Change Managers concerning who should be managing business change. And these are not the only contenders. Corporate executives and senior managers, although they may engage the assistance of both Project Managers and Change Managers, generally see themselves as taking the leading roles in managing major organisational changes and transformations. As such endeavours are most likely to take the form of programs, comprising multiple projects across the organisation, Program Managers are seen by some as being most likely to be responsible for managing organisational change initiatives. This paper reports on research undertaken to explore the differences in approach and practice of Project, Program and Change Managers as a basis for determining the competencies required to effectively manage change initiatives.
\end{abstract}




\section{Competencies for Managing Change}

\section{Introduction}

In the project management field, organisational changes have become recognised as a distinct type of project or program (Partington, 1996) that has generated a growing research interest (Levene and Braganza, 1996; Crawford et al. 2003; Pellegrinelli, 1997; Leybourne, 2006; Bresnen, 2006; Lehtonen and Martinsuo, 2008; Nieminen and Lehtonen, 2008). In the field of change management, organisational change initiatives are often described as projects or programs and reference is made to use of project management skills, tools and techniques (Dover, 2003; Leybourne, 2006; Biedenbach and Söderholm, 2008; Oswick and Robertson, 2009).

In the marketplace, there is evidence of a degree of rivalry between Project Managers and Change Managers concerning who should be managing business change. And these are not the only contenders. Corporate executives and senior managers, are generally the change owners, and although they may engage the assistance of both Project Managers and Change Managers, generally see themselves as taking the leading roles in major organisational changes and transformations. As such endeavours are most likely to take the form of programs, comprising multiple projects across the organisation, Program Managers are seen by some as being most likely to be responsible for managing organisational change initiatives (Pellegrinelli et al. 2007).

There is a popular view in the project management community that Project Managers are managers of change or change agents (Turner et al., 1996), but others (Partington et al. 2005) consider that projects or programs that require significant amounts of behavioural and organisational change, particularly those that might be characterised as involving $2^{\text {nd }}$ order change (Levy \& Merry, 1986; Gareis, 2009) demand high levels of interpersonal skill, astuteness and sensitivity and a fundamentally different approach to the candid, direct, and rational style valued in competent project managers. They also suggest that Project Managers, or Project Managers promoted to Program Manager roles are not always suited to the demands of organisational change 
projects. They need to learn skills and capabilities beyond those required to manage a typical project in order to drive change.

In practice the role of the Change Manager has emerged from a different disciplinary background to that of Project Managers. Project management can be seen as having its origins in engineering with a focus on planning and control while organisational change as a discipline has grown from the Organisational Development field (Vaill, 1989) and places significant emphasis on the behavioral aspects of managing change. This leads to the recognition that there are two distinct bodies of knowledge underpinning the practices of the Project Manager and the Change Manager. The project management body of knowledge is well defined in standards and guides produced by the project management professional associations. The field of organisational change and development is less well served in terms of professional and representative bodies (Hughes, 2007, p. 47) and practice standards but arguably much richer in terms of theoretical foundations. Consideration of both fields suggests that Change Managers coming from organisational development backgrounds may lack the technical and administrative discipline of project management, while Project Management qualifications offered by the professional associations and even the majority of academic institutions do not require Project Managers to demonstrate practice or underpinning knowledge in organisational development or behavioural aspects of change (Pellegrinelli, 2002). There is certainly evidence that poor management of human factors is associated with failure of organizational change projects (Buchanan and Boddy, 1992; Todnem, 2005; Luo et al. 2006; Maguire and Redman, 2007).

The role and professional background of the person best suited to manage change is a topic of often-impassioned debate in the literature and in practice. There are many who believe that this role should be performed by the Project or Program Manager (Obeng, 1994; Turner et al., 1996; Pellegrinelli, 1997; Kliem et al., 1997). Other authors believe that the person managing change should come from a background which is less technical or project-based and more focused on behavioral science such as human resources, organizational development, and/or psychology (Kanter et al., 1992; Connor and Lake, 1994; French and Bell, 1999; Cummings and Worley, 2001; 
Caluwé and Vermaak, 2003). The OGC’s Managing Successful Programmes (Office of Government Commerce (OGC), 2007) envisages that roles of both Programme Manager and Business Change Manager will be involved in the management of change initiatives.

As mentioned earlier, Project and Program Managers' roles are well-established in literature, in practice, in academia and by professional bodies such as the Project Management Institute (PMI) and the International Project Management Association (IPMA). Change Management roles are not as clearly articulated. Job sites such as “My Career," “Monster,” and “Seek” provide evidence of consistent demand for Change Managers, but role definition and support is considerably less well developed than it is in the project management field. Although a Change Management Institute (CMI), with global aspirations, was formed in Sydney in 2005 to meet "the professional development needs of Change Managers through the provision of networking, education and accreditation” (Change Management Institute, 2009), professional bodies for change management are not as well established as they are for project management and there is very little literature support for specific change management roles. The change management literature focuses more on theories and processes of change than on the definition of roles of those involved in its implementation. Many actors, at different levels of the corporate hierarchy, are seen as involved in effecting organisational change. Reference is made to change leaders, change agents, change managers, change drivers, interim managers (Smid et al. 2006), organisational development consultants (French and Bell, 1999; Caluwé and Vermaak, 2003), as well as an “external consultant or internal project leader” (Jarrett, 2004, p.246; Jarrett, 2004). Although the use of projects to implement change (Biedenbach and Söderholm, 2008) and the need for project management skills (Nikolaou et al. 2007) are mentioned, the change management literature does not specifically identify a need for Project or Program Managers.

This paper reports on research that aims to contribute to the emerging and very practical debate about choice of managers of change projects by examining the competencies required to manage change. 


\section{Methodology}

There are two parts to this research study. First, the project and change management literatures have been reviewed to provide a comparative analysis of the competencies expected of Project, Program and Change Managers. Such a comparison provides a useful basis for determining whether Project and Program Managers can be expected to have the necessary competencies for management of organizational change. Having examined the literature, a similar comparison is conducted of practice across three case studies of organizational change projects. The case studies were carefully selected to provide practical insights into the relative roles and contributions of both Project / Program Managers and Change Managers in the implementation of organizational change. Taking a performance based view of competence (Heywood et al., 1992; Crawford, 2005) the activities undertaken by Project / Program Managers on the case study projects are compared with those of the Change Managers.

\section{Comparative competencies from the literature}

Crawford (2002) identified aspects of project manager competency by comparing the findings of a number of research based studies. Aspects of competency were grouped and then ranked according to the number of times they were mentioned across eight studies. Those aspects receiving the least number of mentions were progressively grouped with the most directly related aspect receiving a higher number of mentions, and the aspects re-ranked. This procedure was conducted iteratively, resulting in the emergence of twenty four competency aspects encompassing knowledge, skills and personal attributes identified as important to effective project management performance.

Results from Crawfords' (2002) study were updated and enhanced by inclusion of data from five additional studies and five standards including the ICB (International Project Management Association, 2006), APMBoK (APM, 2006), PMBOK ${ }^{\circledR}$ Guide (PMI, 2004), GAPPS standards (GAPPS, 2007) and OGC Successful Delivery Skills Framework (Office of Government Commerce (OGC), 2004). 
The same analytical process was then applied to derive comparable sets of competencies for Program Managers and Change Managers. Results of the analysis are shown in Table 1.

\section{Case Studies}

Three case studies of organizational change projects were studied in three different organizations. Both organizations and change projects were carefully chosen to provide as much control as possible over variation. The three organizations were of similar size but in three different industry sectors:

1. A large telecommunications company with 9,000 employees

2. A financial institution with 12,000 employees (before a merger, under which grew it to 30,000$)$

3. A public university with 10,000 employees

To have as much control as possible over the type of change project, its influence and its measurability, the change projects were also chosen based on a set of criteria:

- Type of change: All change projects are an implementation of an organizationwide IT system. These are the most common changes found in organizations today. All change projects may be considered $1^{\text {st }}$ order changes as the overall identities of the parent organizations were not changed.

- Number of influenced staff: Each organizational change has been implemented for a minimum of 1,000 people and a maximum of 3,000 people within the organization.

- Project expenditure: cost for implementing each of these major technological implementations ranges from \$5 million up to \$20 million.

For all projects, the change had already taken place, the project or program had been completed, and the results of the change had been measured or could be estimated when the study was conducted. The change initiates were chosen on the basis that there was successful implementation as perceived by the sponsor. A critical factor in choice was that one was managed by a Change Manager, one by a Project Manager, 
and another by both a Change Manager and a Project Manager. For each project, semi-structured interviews were conducted with the leader/s of the change project, whether that was the Project Manager, the Change Manager, or both; the sponsor of the change initiative; three employees influenced by the organizational change; and a project team member (see Figure 1).

In practice, it was not possible to differentiate roles of Project and Program Manager as in these case studies the terms project and program were used interchangeably throughout the interviews. The term project was most commonly used. This is indicative of the pervasiveness of the term project, the less mature recognition and understanding of program and the questionable perception of program management roles as a progression from Project Manager in career terms as identified by Pellegrinelli et al.(2007).

\section{Case Study 1 Case Study 2 Case Study 3 \\ Financial Institution \\ 12,000 employees \\ Change Manager \\ Academic Institution \\ 10,000 employees \\ Telecommunications \\ 9,000 employees \\ Project Manager

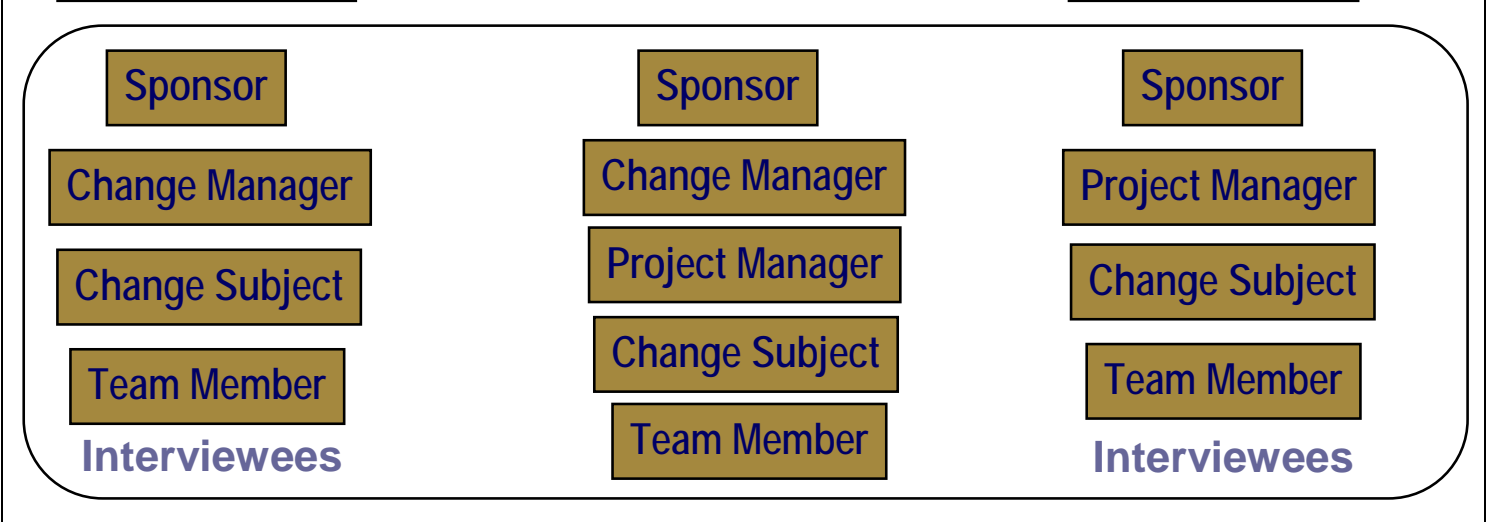

Figure 1: Participant structure

The key contact in each organisation was the project sponsor, who identified and invited participants. Interviewees were told that the research study would investigate both the Project / Program Manager and the Change Managers roles. Semi-structured interviews were conducted, transcribed and then analyzed using grounded theory techniques (Strauss, 1998) with the aid of NVivo qualitative data analysis software. 


\section{Discussion}

From the literature, competencies expected of Project, Program and Change Managers were found to have similarities, although there were some differences as identified in Table 1.

Table 1: Literature based project, program and change management competencies across the three roles

\section{Project Manager}

Program Manager

Change Manager

\begin{tabular}{|c|c|c|}
\hline \multicolumn{3}{|c|}{ Similar Competencies } \\
\hline Leadership & Leadership & Leadership \\
\hline $\begin{array}{l}\text { Team development / Team } \\
\text { selection }\end{array}$ & $\begin{array}{l}\text { Team development / Resource } \\
\text { development }\end{array}$ & Team development \\
\hline Stakeholder management & Stakeholder management & Stakeholder management \\
\hline \multirow[t]{2}{*}{ Communication } & Communication & Communication \\
\hline & Cultural consideration & Cross cultural skills \\
\hline $\begin{array}{l}\text { Decision-making and problem- } \\
\text { solving }\end{array}$ & & Decision-making and problem-solving \\
\hline $\begin{array}{l}\text { Planning: cost, time, risk, quality, } \\
\text { scope }\end{array}$ & Planning & Planning / Project management skills \\
\hline Governance & Governance management & \\
\hline Contract management & Commercial & \\
\hline $\begin{array}{l}\text { Monitoring and controlling: cost, } \\
\text { time, risk, quality, scope }\end{array}$ & $\begin{array}{l}\text { Risk and issues management, } \\
\text { scope management, progress } \\
\text { monitoring, quality management }\end{array}$ & \\
\hline \multicolumn{3}{|c|}{ Different competencies } \\
\hline Organisation structure & $\begin{array}{l}\text { Project management office } \\
\text { consideration }\end{array}$ & Analysis and assessment \\
\hline Project definition & Benefits management & Creativity and challenge \\
\hline $\begin{array}{l}\text { Administration, project reporting } \\
\text { and documentation }\end{array}$ & & Initiative and self management \\
\hline Transition management & & Coaching skills \\
\hline Change control & & Facilitation skills \\
\hline \multirow[t]{6}{*}{ Closing } & & Presentation skills \\
\hline & & Process design \\
\hline & & Learning and development \\
\hline & & Action orientation \\
\hline & & Strategic thinking \\
\hline & & Influencing skills \\
\hline
\end{tabular}

Crawford, L. H. \& Hassner-Nahmias, A.(2009). Competencies for Managing 
In the case studies, however, greater differences were found between what Project / Program Managers and Change Managers actually do. The focus here is on change related activities (See Table 2). As noted above, it was not possible in the case studies to differentiate between Project and Program Managers as the interviewees used the terms interchangeably.

Table .2: Similar and different activities undertaken by Project / Program and Change Managers in the case studies Project / Program Managers Change Managers

\begin{tabular}{|l|l|}
\hline \multicolumn{2}{|c|}{ Similar change related activities } \\
\hline $\begin{array}{l}\text { Communicating-organizes presentations, } \\
\text { represents the project at team meetings and } \\
\text { reports to sponsors }\end{array}$ & $\begin{array}{l}\text { Communicating with stakeholders and } \\
\text { managing their expectations }\end{array}$ \\
\hline $\begin{array}{l}\text { Stakeholder management and management of } \\
\text { teams with interface to the project }\end{array}$ & Stakeholder management \\
\hline Planning & Different activities \\
\hline $\begin{array}{l}\text { Managing resources, people, budget schedule, } \\
\text { risk }\end{array}$ & $\begin{array}{l}\text { Changing behaviors and organizational } \\
\text { culture to achieve the goals }\end{array}$ \\
\hline Team development & Preparation of users \\
\hline System assessment & Organizational structure \\
\hline Project definition & Political diffusion \\
\hline Issues resolution & Impact analysis \\
\hline Vendor management & Selling the change \\
\hline Strategic decisions & Champion schemes \\
\hline Preparation of work environment & Involvement in process analysis work \\
\hline Project closing from project to operational & Training and education to affected staff \\
\hline
\end{tabular}

The review of the literature suggested a greater similarity between expected competencies of Project / Program Managers and Change Managers than was evidenced by the activities they carried out in practice. As indicated in Table 2, Project Managers focus on core Project Management activities and conduct few 
directly change management related activities. Similarities are in communication, stakeholder management and planning but in each case the focus of Project Managers and Change Managers is different.

Change Managers use communication primarily to engage stakeholders, sell change, enlist champions, facilitate political diffusion and manage stakeholder expectations. Communications activities of Project Managers are primarily concerned with involvement in meetings, presentation of the project, and reporting particularly to sponsors. The focus of Change Managers is more on engagement rather than management of stakeholders, taking a wide view of stakeholders with particular emphasis on users and those affected by change. Project Managers, on the other hand, are more comfortable with the concept of stakeholder management and although they may identify a wider range of stakeholders, their concern centres on team members and project interfaces. Change Managers focus on planning to effect and embed change. The primary concern of Project Managers is planning for the project.

The change management literature makes it clear that context is a major factor in determining the approach that should be taken which will in turn influence the competencies required. A major finding from the case studies in relation to context was that some organizational factors such as supportive culture and leadership assisted projects in achieving their goals although they did not completely eliminate the requirement for change management activities. For instance, in the Telco, with only a Project Manager and no dedicated change management resource, few change management related activities were undertaken by the Project Manager who focused on project management related activities. Team members and affected staff commented on this in interviews and noted that a greater focus on change management including communication would have been beneficial. However there was general agreement that the project was successful and this appears to be largely due to a shared view that the change was necessary, strong management leadership for the change and existence of a strong and well supported project management culture within the organisation. This suggests that where there is a culture that recognizes the value of project management, good teamwork, low change resistance and strong leadership supporting the change it may succeed, regardless of the quality of change 
management activities. Factors that are influenced by the change project are the degree of behavioral change required and the extent of changes to the way people perform their jobs. These were influenced in the case studies using project engagements, communication, training, and process redesign.

Concepts of $1^{\text {st }}$ and $2^{\text {nd }}$ order change provide another lens through which to consider the roles and competencies required to manage change initiatives. $2^{\text {nd }}$ order change, being “discontinuous, deep structural and cultural change”(Gareis, 2009) could be considered to required greater breadth and depth of change management competencies and activities.

Reflection on the findings of this study were distilled to produce a matrix to assist managers and practitioners in making decisions concerning the competencies required and the resourcing and management of change initiatives.

\section{Guide for deciding on change project management structure}

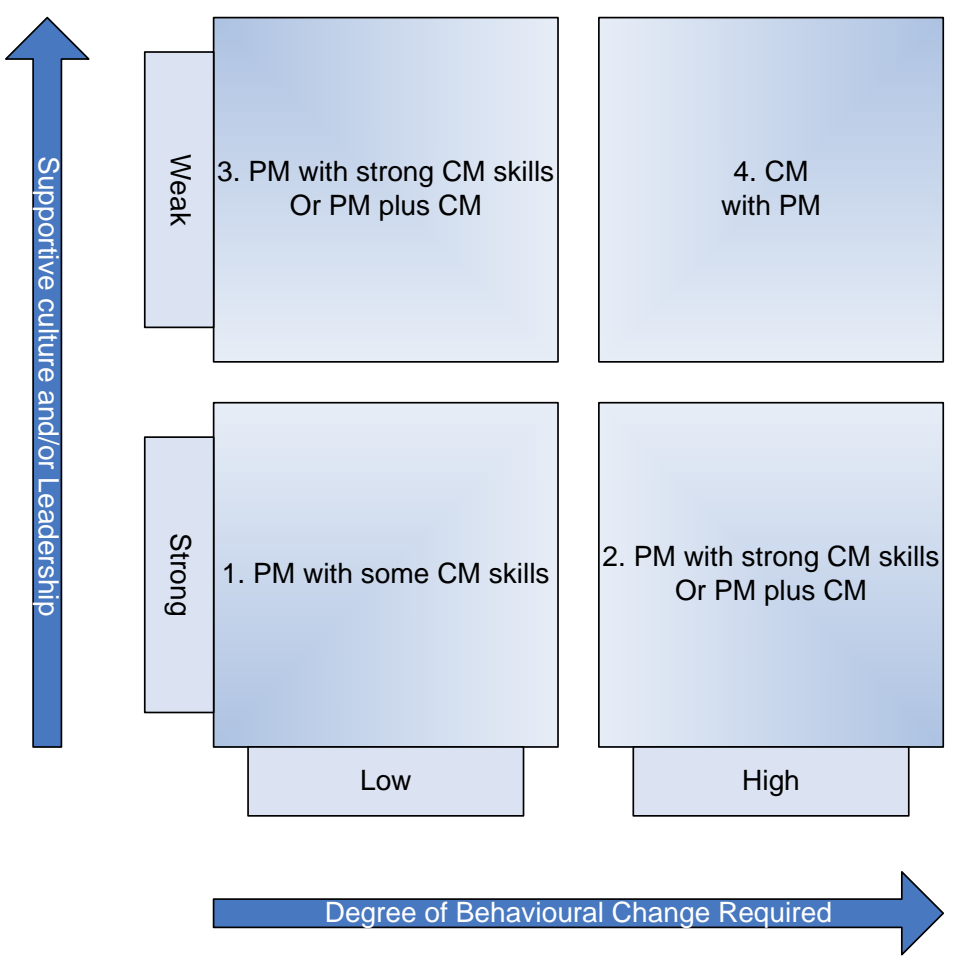

Figure 2: Suggested decision matrix for engagement of project (PM) and/or Change Managers (CM) 
The two axes represent the key contextual factors found in this research to influence the intensity of change management activities required. A high degree of behavioral change and a weak supportive culture and leadership will require more intensive change management activities, highlighting the need for competent resources dedicated to change management. At the other end of the spectrum, if there is little behavioral change required and there is strongly supportive culture and leadership, then the change may be effectively managed by a Project Manager with some change management skills. Other scenarios would suggest Project Managers with varying degrees of change management competence and / or engagement of both a Project Manager and a Change Manager.

A key finding from the case studies is that, except in projects where there is very little behavioural change required, the Project / Program Manager will not have the time or bandwidth to carry out all the change management activities required to ensure a successful outcome. For relatively small scale change initiatives a Change Manager with some project management skills may be an appropriate choice especially as project management skills are regularly identified as one of a number of competencies required in the Change Manager's arsenal (Change Management Institute, 2008). Nikolaou et al ( 2007, p. 298) claim that "a change agent must rely on skills from both project management and organizational development (OD)" and in their study of traits and skills of change agents found that only project management skills demonstrated a significant positive correlation with overall team performance, even when the effect of dispositional characteristics such as openness to experience, resilience, self efficacy, resistance to change, cognitive and affective attitudes and behavioural tendencies were taken into account (p. 306).

In this study we have focused on performance based competencies that are evidenced by what is done in the workplace, rather than personal competencies. The change management literature strongly emphasises the importance of personal competencies to effective change management. It may be assumed that not all Project and Program Managers are dispositionally suited to management of change, although the findings of Nikolaou et al. (2007) supported by others such as Bruch et al. (2005), reporting on strategic change implementation at Lufthansa, and Leybourne (2006) relating to 
project-managed implementation of strategic change in the UK financial services sector, provide some confidence that change initiatives will generally benefit from some form of project management.

\section{A guide for Project / Program and change management competencies and activities}

In this study both literature and empirical research were utilized to provide a guide to the competencies required and activities to be undertaken by a Project / Program Manager and Change Managers to successfully implement change on change projects.

Table 3 below summarises the change management competencies that were found in literature across the roles of the Project / Program Manager and the Change Manager. These competencies, according to literature, are those needed by Project / Program and Change Managers to implement change successfully as part of a change project. Table 3 presents the change management activities that were undertaken by the Change Managers on the case study change projects. These findings are consistent with guidance from the change management literature.

In summary, in order for an individual, whether Project / Program or Change Manager, to successfully implement change into organizations, he or she should possess all the competencies listed in Table 2 common across the roles and summarised in column one of Table 3 below. They must also be able to perform, or ensure performance of the activities listed in column two of Table 3, as they are directly related to proven achievement of successful change. 
Table 3: Competencies and activities required to manage change based on synthesis of findings from literature and case studies

\begin{tabular}{|l|l|}
\hline \multicolumn{1}{|c|}{ Competencies required } & \multicolumn{1}{c|}{ Change activities to be undertaken } \\
\hline Leadership & $\begin{array}{l}\text { Changing behaviors and organizational culture to } \\
\text { achieve goals }\end{array}$ \\
\hline Stakeholder management & Preparation of users \\
\hline Planning & Organizational structure \\
\hline Team selection/ team development & Political diffusion \\
\hline Communication & Impact analysis \\
\hline Decision-making and problem-solving & Selling the change \\
\hline Cultural awareness / skills & Champion schemes \\
\hline Project management skills & Involvement in process analysis work \\
\hline & Training and education to affected staff \\
\hline
\end{tabular}

\section{Conclusion}

The goal of this study was to investigate the relative roles of Project / Program Managers and Change Managers on organizational change projects and the contextual factors that might affect the change management competencies required, the change activities that need to be undertaken, and the most appropriate professional background to manage the process. Analysis of literature and rich data drawn from carefully selected case studies has contributed to theoretical and practical understanding of the phenomenon and provides a sound basis for future research testing the findings in other settings and with different methodologies. In this study, the types of change projects were all IT implementations conducted in different types of organizations. This is an important limitation of the study. Although findings have support from the literature and provide useful guidance for further research, they lack generalisablity and recommendations should be treated with caution. Studies of different types of organizational change would be a useful further progression of this research. Categorization of $1^{\text {st }}$ and $2^{\text {nd }}$ order change, as discussed by Gareis (2009) could provide a useful framework for such studies. 
The organizational factors identified as significant in this research were specific to those the three cases studied. There are many other factors in organizations that influence or are influenced by organizational change projects. It would be worthwhile investigating organizational/contextual factors in greater depth, perhaps investigating each factor separately. A study such as this would contribute greatly to the understanding of how contextual factors influence the competencies required to effectively implement change.

This study has implications for both the theory of project management and change management. From a theoretical perspective, this study brings together two largely disparate fields that operate within the same organizational territory, that is, the management of change. The two fields are project / program management and change management, a field which has evolved from organizational development and human resources practices. In practice, there is often competition between Project / Program Manager and Change Managers for the management role on organizational change projects but this study has demonstrated that there is opportunity for a fruitful partnership. From a theoretical perspective, change management can be seen as theory-rich while the role of the Change Manager is weakly supported in terms of professional formation. The project / program management field is generally considered to be theory-poor, while the roles of Project and Program Manager are very well supported by professional bodies, standards, and certification processes. This suggests a fruitful opportunity for partnership not only in the management of organizational change projects, but in theoretical and professional development.

Another contribution of this study is in testing the claims of Project and Program Managers as implementers of change. According to this study, and in contradiction to many papers and books written to date on the matter, Project and Program Managers do not necessarily have the required competence or perform the full activities required to promote and implement the changes that they are leading as part of their projects. Although many authors suggest that Project and Program Managers are implementers of change, the case studies analyzed do not support this when compared to Change Managers. The findings of this research have potential to contribute to curriculum and educational development for Project and Program Managers. 
The study highlights the need for professional formation for Change Manager roles which have significant application in practice, but have been subjected to little scrutiny in terms of research. To date, there are few or no industry bodies representing change management roles, there are few academic courses designed to cater specifically for such roles and there is no agreed governance for how the roles might be executed or "how ethically regulated change management practice might develop" (Hughes, 2007, p. 47). The growing popularity of the Change Manager role suggests a need for professionalization.

In a practical sense, as a result of this study, a set of change management competencies, change related activities and a matrix to assist in decisions about appointment of a Project Manager or Change Manager or both for organizational change projects have been presented. Results support the already well-practiced use of a Change Manager in the management of change and enhance understanding of how the Project / Program Manager and Change Manager relate to one another on change projects. In recruitment for organizational change projects there needs to be consideration for the management of the change and the person who will drive the changes into the organization beyond the daily tasks of managing the Project / Program, performed by the Project / Program Managers. The implications of having this additional role are in changes to the way projects are run, including their governance, reports, and all other project activities as well as the development of new project activities which are change management-specific.

\section{References}

APM (2006) Body of Knowledge 5th Edition, High Wycombe: Association for Project Management.

Biedenbach, T. and Söderholm, A. (2008) The Challenge of Organizing Change in Hypercompetitive Industries: A Literature Review. Journal of Change Management 8 (2):123-145.

Bresnen, M. (2006) Conflicting and conflated discourses? Project management, organisational change and learning. In: Hodgson, D.E. and Cicmil, S.J.K., (Eds.) Making projects critical, New York: Palgrave Macmillan

Bruch, H., Gerber, P. and Maier, V. (2005) Strategic change decisions: doing the right change right. Journal of Change Management 5 (1):97-107.

Buchanan, D.A. and Boddy, D. (1992) The Expertise of the Change Agent. Prentice Hall.

Crawford, L. H. \& Hassner-Nahmias, A.(2009). Competencies for Managing

Change. International Journal of Project Management, Submitted for publication. 
Caluwé, L.D. and Vermaak, H. (2003) Learning to change: a guide for organisational change agents, Thousand Oaks, CA: Sage Publications.

Change Management Institute. (2008)Change Management Practitioner Competencies [Web Page]. Available at http://www.change-management-institute.com/Upload/CMI-Competency-Model010408.pdf. (Accessed 10 September 2008).

Change Management Institute. (2009)Welcome to the Change Management Institute [Web Page]. Available at http://www.change-management-institute.com/. (Accessed 20 July 2009).

Connor, P.E. and Lake, K.L. (1994) Managing organisational change, Westport, CT: Praeger Paperback.

Crawford, L., Costello, K., Pollack, J. and Bentley, L. (2003) Managing soft change projects in the public sector. International Journal of Project Management 21 (6):443-448.

Crawford, L.H. (2002) Profiling the competent project manager. In: Slevin, D.P., Cleland, D.I. and Pinto, J.K., (Eds.) The frontiers of project management research, pp. 151-176. Newtown Square, Pennsylvania: Project Management Institute

Crawford, L.H. (2005) Senior Management Perceptions of Project Management Competence. International Journal of Project Management 23 (1):7-16.

Cummings, T.G. and Worley, C.G. (2001) Organizational development and change, 7th edn. Cincinnati, Ohio: South-Western College.

Dover, P.A. (2003) Change agents at work: Lessons from Siemens Nixdorf. Journal of Change Management 3 (3):243

French, W.L. and Bell, C.H.Jr. (1999) Organization development : behavioral science interventions for organization improvement, Upper Saddle River, NJ: Prentice Hall.

GAPPS (2007) A Framework for Performance Based Competency Standards for Global Level 1 and 2 Project Managers, Johannesburg: Global Alliance for Project Performance Standards.

Gareis, R. (2009). Designing changes of permanent organizations by processes and projects. International Journal of Project Management, Special Issue: Change Management and Projects. Forthcoming.

Heywood, L., Gonczi, A. and Hager, P. (1992) A Guide to Development of Competency Standards for Professions, Canberra: Australian Government Publishing Service.

Hughes, M. (2007) The Tools and Techniques of Change Management. Journal of Change Management 7 (1):37-49.

International Project Management Association (2006) ICB - IPMA Competence Baseline Version 3.0, Nijkerk, The Netherlands: International Project Management Association.

Jarrett, M. (2004) Tuning into the emotional drama of change: extending the consultant's bandwidth. Journal of Change Management 4 (3):247-258.

Kanter, R.M., Stein, B.A. and Jick, T.D. (1992) The challenge of organizational changes, New York: The Free Press .

Kliem, R.L., Ludin, I.S. and Robertson, K.L. (1997) Project management methodology, a practical guide for the millenium, New York: Marcel Dekker.

Lehtonen, P. and Martinsuo, M. (2008) Change program initiation: Defining and managing the program-organization boundary. International Journal of Project Management 26 (1):21-29.

Crawford, L. H. \& Hassner-Nahmias, A.(2009). Competencies for Managing

Change. International Journal of Project Management, Submitted for publication. 
Levene, R.J. and Braganza, A. (1996) Controlling the work scope in organisational transformation: A programme management approach. International Journal of Project Management 14 (6):331-340.

Levy, A. \& Merry, U. (1986). Organizational transformation: approaches, strategies, theories. New York: Praeger.

Leybourne, S. (2006) Improvisation within the Project Management of Change: Some Observations from UK Financial Services. Journal of Change Management 6 (4):365-381.

Luo, J.S., Hilty, D.M., Worley, L.L. and Yager, J. (2006) Considerations in change management related to technology. Academic Psychiatry 30 (6):465-9.

Maguire, S. and Redman, T. (2007) The role of human resources management in information systems development. Management Decision 45 (2):252-264.

Nieminen, A. and Lehtonen, M. (2008) Organisational control in programme teams: An empirical study in change programme context: European Academy of Management (EURAM 2007) Conference. International Journal of Project Management 26 (1):63-72.

Nikolaou, I., Gouras, A., Vakola, M. and Bourantis, D. (2007) Selecting Change Agents: Exploring Traits and Skills in a Simulated Environment. Journal of Change Management 7 (3/4):291313.

Obeng, E. (1994) All Change! The Project Leader's Secret Handbook. London: Pitman Publishing.

Office of Government Commerce (OGC) (2004) Successful delivery skills framework, Version 3.0, www.ogc.gov.uk: OGC.

Office of Government Commerce (OGC) (2007). Managing Successful Programmes. (Third ed.) London: TSO (The Stationery Office).

Oswick, C. and Robertson, M. (2009) Boundary Objects Reconsidered: from Bridges and Anchors to Barricades and Mazes. Journal of Change Management 9 (2):179-193.

Partington, D. (1996) The project management of organizational change. International Journal of Project Management 14 (1):13-21.

Partington, D., Pellegrinelli, S. and Young, M. (2005) Attributes and levels of programme management competence: an interpretive study. International Journal of Project Management 23 (2):87-95.

Pellegrinelli, S. (1997) Programme management: organising project-based change. International Journal of Project Management 15 (3):141-149.

Pellegrinelli, S. (2002) Shaping context: the role and challenge for programmes. International Journal of Project Management 20 (3):229-233.

Pellegrinelli, S., Partington, D., Hemingway, C. , Mohdzain, Z. and Shah, M. (2007) The importance of context in programme management: An empirical review of programme practices. International Journal of Project Management 25 (1):41-55.

PMI (2004) A Guide to the Project Management Body of Knowledge (Third Edition), Newtown Square, PA: Project Management Institute.

Smid, G., Van Hout, E. and Burger, Y. (2006) Leadership in organisational change: Rules for successful hiring in interim management. Journal of Change Management 6 (1):35-51.

Strauss, A.L.C.J. (1998) Basics of qualitative research: techniques and procedures for developing

Crawford, L. H. \& Hassner-Nahmias, A.(2009). Competencies for Managing

Change. International Journal of Project Management, Submitted for publication. 
grounded theory, 2nd edn. Thousand Oaks: Sage Publications.

Todnem, R. (2005) Organisational change management: A critical review. Journal of Change Management 5 (4):369-380.

Turner, J.R., Grude, K.V. and Thurloway, L. (1996) The project manager as change agent: leadership influence and negotiation, London: McGraw-Hill.

Vaill, P.B. (1989) Seven Process Frontiers for Organisation Development. In: Sikes, W., Drexler, A.B. and Gant, J., (Eds.) The Emerging Practice of Organisation Development, La Jolla, CA: NTL Institute and University Associates 


\author{
Professor Lynn Crawford \\ Univ Lille Nord de France, F-59000 Lille, France; LSMRC \\ Mirvac School of Sustainable Development, Bond University, Australia \\ Visiting Professor, Cranfield University, UK \\ Director, Human Systems International Limited
}

Lynn Crawford is involved in project management practice, education, and research and is Professor of Project Management at both the Lille Graduate School of Management (ESC Lille), France and Bond University, Australia. Through Human Systems, she works with leading corporations that are developing organizational project management competence by sharing and developing knowledge and best practices as members of a global system of project management knowledge networks. She is currently involved in ongoing research on project and program management competence, and specific research projects on management of business change and differences in project management practices across project types and industries. Lynn provided the Australian contribution to an internationally conducted project on The Value of Project Management and results of other completed research projects have been published as Project Categorization Systems: Aligning Capability with Strategy for Better Results, Situational Sponsorship Of Projects And Programs: An Empirical Review; and Exploring the Complexity of Projects: Implications of Complexity Theory for Project Management Practice. Professor Crawford has been engaged in the development of global standards for project management since the late 1990's and has been instrumental in the formation of the Global Alliance for Project Performance Standards (GAPPS).

\title{
Contact details:
}

Lynn Crawford

Email: Lynn.Crawford@humansystems.net

Tel: +61 410641211

Fax: +61299681274

\section{Dr Anat Hassner Nahmias}

Change Management Leader, Human Capital Practice, Presence of IT, Sydney, Australia

Anat Hassner Nahmias is an Organizational psychologist who was awarded her doctorate at Bond University for research into the roles of the Project Manager and the Change Manager. She has been a Change Manager for the past 10 years working in organizations such as Compaq Computers, NSW Railways, General Motors, the Commonwealth Bank, AMP and Ernst \& Young Australia where she worked on multiple change management assignments. Her work involves changing organizational cultures, processes, systems and structures through projects and programs. 